\title{
Grib kimberlite peridotite xenoliths: isotopic evidence of variable source of mantle metasomatism
}

\author{
NATAliya LebedeVA ${ }^{12}$, ANNA NosOva ${ }^{12}$, AleXeY \\ KARGIN $^{12}$, YULIA LARIONOVA ${ }^{1}$, LIUDMILA \\ SAZONOVA $^{12}$, YANA TIKHOMIROVA ${ }^{2}$ \\ 1 Institute of Geology of Ore Deposits, Petrography, \\ Mineralogy and Geochemistry Russian Academy of \\ Sciences, Moscow, Russian Federation \\ ${ }^{2}$ Vernadsky Institute of Geochemistry and Analytical \\ Chemistry, Moscow, Russian Federation
}

Mantle xenoliths from the Grib kimberlite suggest that lithospheric mantle beneath the Arkhangelsk diamond province had been modified during several stages of mantle metasomatism. The xenoliths show different degree of metasomatic interaction, and they were used to investigate the source of mantle metasomatism.

The most common types of mantle metasomatism among the studied peridotite xenoliths is lherzolitisation by the addition of garnet and clinopyroxene. Clinopyroxene and orthopyroxene from sheared peridotite xenoliths initially have a narrow range (for a kimberlite age; $\mathrm{t}=376 \mathrm{Ma}$ ) of ${ }^{87} \mathrm{Sr} /{ }^{86} \mathrm{Sr}_{(\mathrm{t})}$ (0.70344 and 0.70484 , respectively) and display broader values $\varepsilon \mathrm{Nd}_{(\mathrm{t})}(3.8$ and 1.6). Orthopyroxene and clinopyroxene are in oxygen-isotope equilibrium with coexisting olivine. Clinopyroxene from garnet lherzolite has a considerable variation in ${ }^{87} \mathrm{Sr}^{86}{ }^{86} \mathrm{Sr}_{(\mathrm{t})}(0.70266-0.70582)$ and $\varepsilon \mathrm{Nd}_{(\mathrm{t})}(-4.3-$ 1.0) isotope ratios. Garnet displays elevated initial ${ }^{87} \mathrm{Sr} /{ }^{86} \mathrm{Sr}_{(t)}$ values $(0.705402-0.706327)$. Ilmenite shows a narrow range in ${ }^{87} \mathrm{Sr} /{ }^{86} \mathrm{Sr}_{(t)}(0.70497-0.70522)$ coupled with $\varepsilon N d(t)$ values of 0.4 and 3.5. These isotopic data suggest that this type of mantle metasomatism took place during the interaction of kimberlite melts with SCLM that contained mica-amphibolerutile-ilmenite-diopside (MARID)-type metasomes.

Clinopyroxenes from clinopyroxene-phlogopite (phlogopite wherlite) xenoliths display a broad range in ${ }^{87} \mathrm{Sr} /{ }^{86} \mathrm{Sr}_{(t)}(0.70486-0.70813)$ that is significantly higher than for kimberlite and a relatively narrow range of $\varepsilon \mathrm{Nd}_{(t)}(-0.1-$ $1.3)$ with a restricted $\delta^{18} \mathrm{O}$ range $(5.11 \% 0-5.33 \%$ ). Garnet megacrysts have high ${ }^{87} \mathrm{Sr} /{ }^{86} \mathrm{Sr}_{(\mathrm{t})}(0.70595)$ and $\varepsilon \mathrm{Nd}(\mathrm{t})(-0.3-$ $0.9)$. More-radiogenic Sr-isotopic composition has been induced by metasomatic melt/fluid related to a lithospheric mantle source containing recycled crustal material.

The reported study was funded by RFBR, project № 1935-90037 and by the Russian Science Foundation project № 19-17-00024. 